\title{
Calcium stable isotopes place Devonian conodonts as first level consumers
}

\author{
V. Balter ${ }^{*}$, J.E. Martin¹, T. Tacail², G. Suan¹, S. Renaud ${ }^{3}$, C. Girard ${ }^{4}$
}

\begin{abstract}
OPEN@ACCESS
Abstract

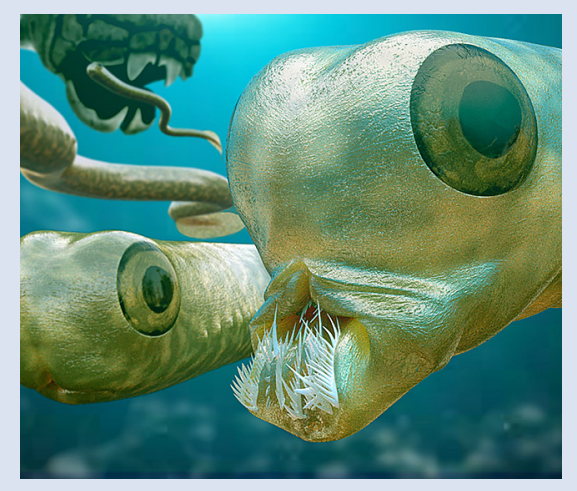

no genus-specific trophic pattern. The question of active predation or scavenging cannot be resolved definitively but our results strongly suggest that Late Devonian conodonts were first level consumers.

Conodont animals are an extinct group of jawless vertebrates whose hard parts, also known as conodont elements, represent the earliest evidence of a mineralised skeleton in the vertebrate lineage. Conodont elements are interpreted as parts of a feeding apparatus, which together with the presence of eyes and microwear patterns, support the controversial hypothesis that conodont animals were macrophagous predators and/or scavengers. Here, we explore the trophic position of five conodont genera (Palmatolepis, Polygnathus, Ancyrodella, Ancyrognathus and Icriodus) from five contemporary Late Devonian sites distributed worldwide (France, Morocco, Vietnam and Australia) by means of calcium (Ca) stable isotope compositions. The seawater Ca isotope composition was calibrated using contemporary Late Devonian brachiopod isotopic values. By comparison with extant marine trophic chain composed of cartilaginous fish, conodont $\mathrm{Ca}$ isotope compositions are indicative of a zooplanktivore - primary piscivore niche, with
\end{abstract}

Received 17 September 2018 | Accepted 17 March 2019 | Published 26 April 2019

\section{Introduction}

Until the publication of the discovery of the first specimen of the conodont animal in 1983 with conodont elements in situ forming a feeding apparatus, the nature and function of the conodont elements was one of palaeontology's great mysteries (Briggs et al., 1983). Since then, several other specimens have shown similar schemes for this feeding apparatus, in which the anterior elements form a structure allowing them to trap food that is further processed by the posterior elements (Purnell and Donoghue, 1997). Today, despite the advancement of synchrotron microtomography that allows reconstructing virtual movements of the elements forming the feeding apparatus (Goudemand et al., 2011), the dietary behaviour of conodonts remains an open debate but recently Shirley et al. (2018) suggested a predatory or scavenger mode of life. Conodonts possessed sclerotic eye capsule and extrinsic eye musculature (Gabbott et al., 1995; Purnell, 1995a), consistent with conodonts having pattern vision and an active predatory lifestyle. Lastly, microwear patterns were found on conodont elements, which constituted the first direct evidence that they functioned as teeth (Purnell, 1995b).

In the present work, which is a pilot study, we use for the first time calcium (Ca) stable isotopes to infer the feeding habit of conodont animals. The first studies showing that trophic levels of animals, including fish, could be inferred from the Ca isotope compositions of their shell or inner skeleton lay back in the 2000's (Skulan et al., 1997; Skulan and DePaolo, 1999; Clementz et al., 2003; DePaolo, 2004). These results were recently confirmed on modern and fossil elasmobranchs (Martin et al., 2015), a subclass of cartilaginous fish, including the sharks, rays and skates, and sawfish. Some authors have already measured the Ca isotope composition of conodonts but with the aim to reconstruct variations of the seawater composition (Hinojosa et al. 2012; Jost et al. 2014; Le Houedec et al. 2017). Here, the Late Devonian period, particularly the Frasnian-Famennian boundary (F/F), was chosen because it is accompanied by important variations in the shape of conodont elements, suggestive of changes in the feeding behaviour of several genera (Balter et al., 2008; Girard and Renaud, 2008). The Material and Method sections are described in the Supplementary Information.

\section{Results}

All values presented in this work are expressed as $\delta^{44 / 42} \mathrm{Ca}$ and defined as $\delta^{44 / 42} \mathrm{Ca}=\left(\left({ }^{44} \mathrm{Ca} /{ }^{42} \mathrm{Ca}_{\text {sample }}\right) /\left({ }^{44} \mathrm{Ca} /{ }^{42} \mathrm{Ca}\right.\right.$ SRM915a $\left.)-1\right)$ * 1000. All measured samples were plotted as $\delta^{43 / 42}$ Ca against

\footnotetext{
1. Laboratoire de Géologie de Lyon. UMR 5276 CNRS, ENS Lyon, Univ. Lyon1. 46, Allée d'Italie, 69342 Lyon Cedex 07, France

2. Bristol Isotope Group, School of Earth Sciences, University of Bristol, Wills Memorial Building, Queen's Road, Bristol, BS8 1RJ, UK

3. Laboratoire de Biométrie et Biologie Evolutive. UMR 5558 CNRS, Univ. Lyon1. Bâtiment Mendel. 43, bd du 11 novembre 1918, 69622 Villeurbanne Cedex, France

4. Institut des Sciences de l'Evolution de Montpellier. UMR 5554 CNRS, Univ. Montpellier 2 Place Eugene Bataillon, 34095 Montpellier Cedex 05, France Corresponding author (email: Vincent.Balter@ens-lyon.fr)
} 


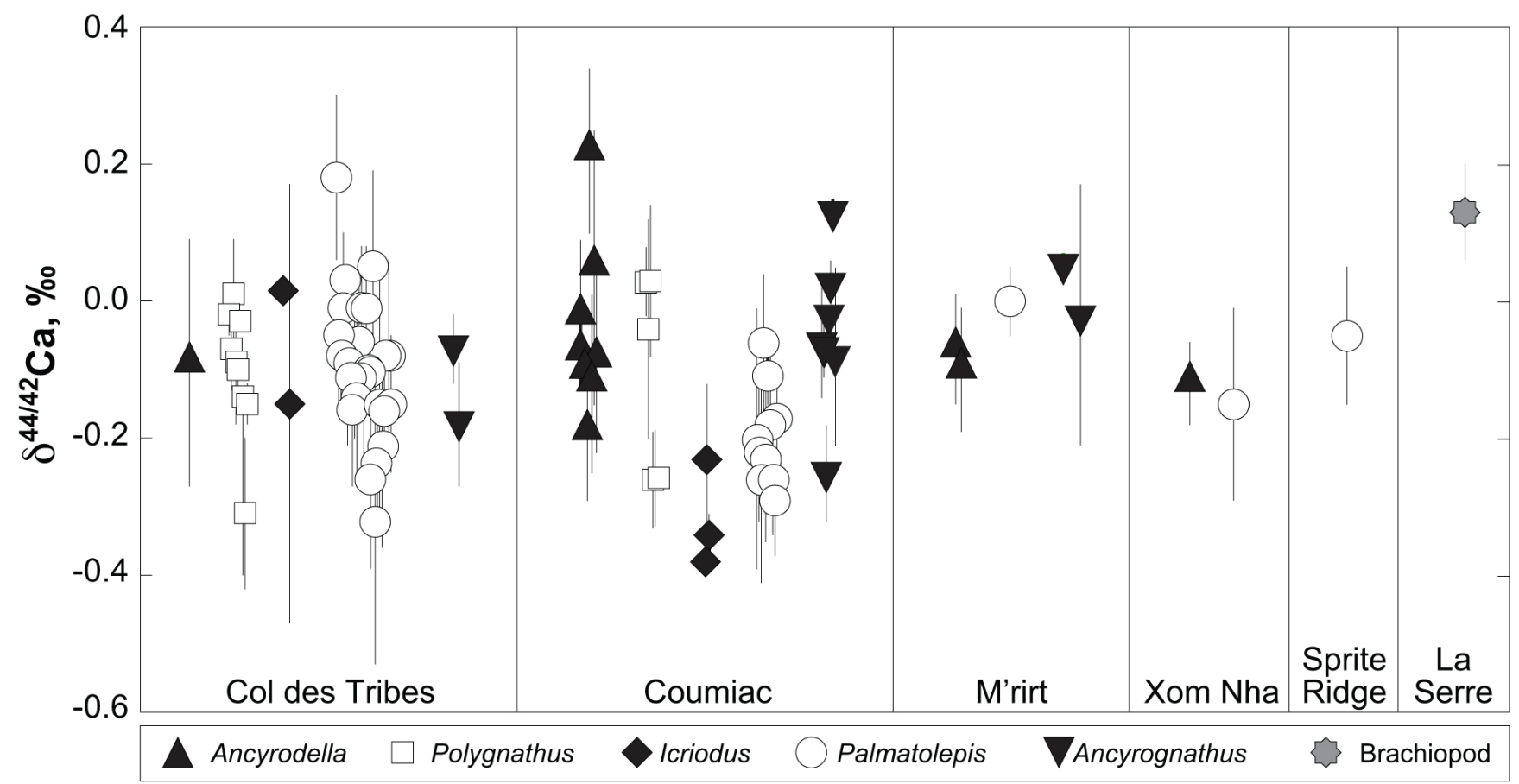

Figure 1 Ca isotope compositions of conodonts ( $\left({ }^{44 / 42} \mathrm{Ca}\right)$ relative to SRM915a (\%) measured in the study.

$\delta^{44 / 42} \mathrm{Ca}$ and fall on a line with a slope of 0.557 close to the theoretical 0.507 slope predicted by the exponential approximation of mass dependent fractionation (Tacail et al., 2014; Fig. S-2). Quality control assessment is given in Table S-2, and $\mathrm{Ca}$ isotope values of conodonts measured in this study (Table S-3; Fig. 1) range from $-0.38 \%$ to $0.22 \%$, with an average value of $-0.10 \pm 0.22 \%$ o \pm 2 s.d., $\mathrm{n}=80)$. The average $\delta^{44 / 42} \mathrm{Ca}$ value is $-0.10 \pm 0.20 \%( \pm 2$ s.d., $\mathrm{n}=39)$ at Col des Tribes, $-0.12 \pm 0.28 \%$ o ( \pm 2 s.d., $\mathrm{n}=39)$ at Coumiac, $-0.03 \pm$ $0.12 \%$ o ( \pm 2 s.d., $n=5)$ at M'rirt, $-0.14 \pm 0.04 \%$ o ( \pm 2 s.d., $n=2)$ at Xom Nha and $-0.05 \%$ at Sprite Ridge (Table S-3). Comparison between conodonts at Coumiac and Col des Tribes, the two most abundant sites, reveals no significant difference of the $\delta^{44 / 42}$ Ca value (Student's $t$-test, $\mathrm{p}=0.373$ ). Comparisons between conodonts grouped by genus reveal no taxonomic difference (Table S-4). The brachiopod yielded a $\delta^{44 / 42} \mathrm{Ca}$ value of $0.13 \%$ o (Table S-1), which represents one of the highest values of the dataset.

\section{Discussion}

The present paper focuses on the trophic position of conodont animals based on their Ca isotope compositions, but these could have been affected by diagenetic processes. Discussion on the effects of diagenesis is developed in the Supplementary Information. We conclude, in the absence of any evidence of Ca isotope compositions being diagenetically reworked, that the measured $\delta^{44 / 42} \mathrm{Ca}$ values of conodonts are biogenic.

The present paper focuses on the trophic position of conodont animals based on their Ca isotope composition, but accurate comparisons with modern analogues first necessitate calibrating the $\mathrm{Ca}$ isotopic values of the conodont elements relative to that of the contemporaneous seawater. Based on the existing $\mathrm{Ca}$ isotopic fractionation factor between modern brachiopods (br) Terebratalia and seawater (sw), $\alpha_{\mathrm{br}-\mathrm{sw}}=$ 0.99915 (Gussone et al., 2005), the $\delta^{44 / 42} \mathrm{Ca}$ value of end-Devonian seawater $\left(\delta^{44 / 42} \mathrm{Ca}_{\mathrm{sw}}\right)$ was estimated at $0.55 \%$, i.e. $\sim 0.4$ $\%$ ower than that of modern oceans (Blättler et al. 2012). With an age estimated slightly younger than the Devonian-Carboniferous boundary of $360 \mathrm{Ma}$, this value falls in the range, but in the lower limit, of the reconstructed Phanerozoic seawater Ca isotope composition of Farkaš et al. (2007; Fig. S-3). We can now calculate the Ca isotopic offset between seawater and conodonts, which is equal to $0.65 \pm 0.25 \%$, $( \pm$ s.d., $n=80)$. Conodonts are made up of hydroxylapatite (hap), which is more or less fluorinated, but it is the same mineral phase as that of elasmobranch teeth. This allows comparing the average Ca isotopic offset between Devonian seawater and conodonts with that of modern seawater and extant elasmobranch tooth enameloid (Martin et al. 2015), which is annotated $\Delta^{44 / 42} \mathrm{Ca}_{\mathrm{sw} \text {-hap }}$ (Fig. 2). Using a modern seawater $\delta^{44 / 42} \mathrm{Ca}_{\mathrm{sw}}$ value of $0.92 \%$, an offset of $\sim 0.65 \%$ is observed nowadays between seawater and the zooplanktivore and primary piscivores group, which are characterised by average $\Delta^{44 / 42} \mathrm{Ca}_{\text {sw-hap }}$ values of $0.56 \pm 0.27 \%$ o ( \pm 2 s.d., $\mathrm{n}=5)$ and $0.86 \pm 0.08 \%$ o $( \pm 2$ s.d., $\mathrm{n}=6$ ), respectively (Fig. 2 ). To fully encompass the $\delta^{44 / 42} \mathrm{Ca}_{\text {sw }}$ variability at that time, which is well described by the study of Farkaš et al. (2007), we can also calculate the $\Delta^{44 / 42} \mathrm{Ca}_{\text {sw-hap }}$ with the upper limit of the contemporaneous $\delta^{44 / 42} \mathrm{Ca}_{\mathrm{sw}}$ value, i.e. $\sim 0.67 \%$ o. Even with this higher value, the calculated $\Delta^{44 / 42} \mathrm{Ca}_{\text {sw-hap }}$ offset shows that conodonts are still in the the zooplanktivore - primary piscivores group (Fig. 2). The observation that conodonts fall as first level consumers is in accordance with the macrophagous hypothesis (i.e. feeding on relatively large particles of food), but is at odds with the view that conodont animals had a purely predatory lifestyle, which would have implied a $\delta^{44 / 42}$ Ca value of conodont elements around $1 \%$. Scavenging of fish cannot be ruled out, but must have involved small fish above all, otherwise the $\delta^{44 / 42} \mathrm{Ca}$ values would have been those of predators.

Another argument in favour of a basal trophic position for conodonts, is that modern piscivore elasmobranchs exhibit a much tighter grouping of the $\delta^{44 / 42} \mathrm{Ca}$ values than modern zooplanktivore elasmobranchs and conodonts (Figs. 1 and 2). The range of $\delta^{44 / 42} \mathrm{Ca}$ values for a given trophic level of piscivore elasmobranchs never exceeds $0.1 \%$ while it is higher than $0.2 \%$ o for modern zooplanktivore elasmobranchs and conodonts. No definitive explanation can be put forward from the state of the results, but a reasonable hypothesis could be that animals at the bottom of the trophic chain are more likely to sample local isotopic heterogeneities. This variability 


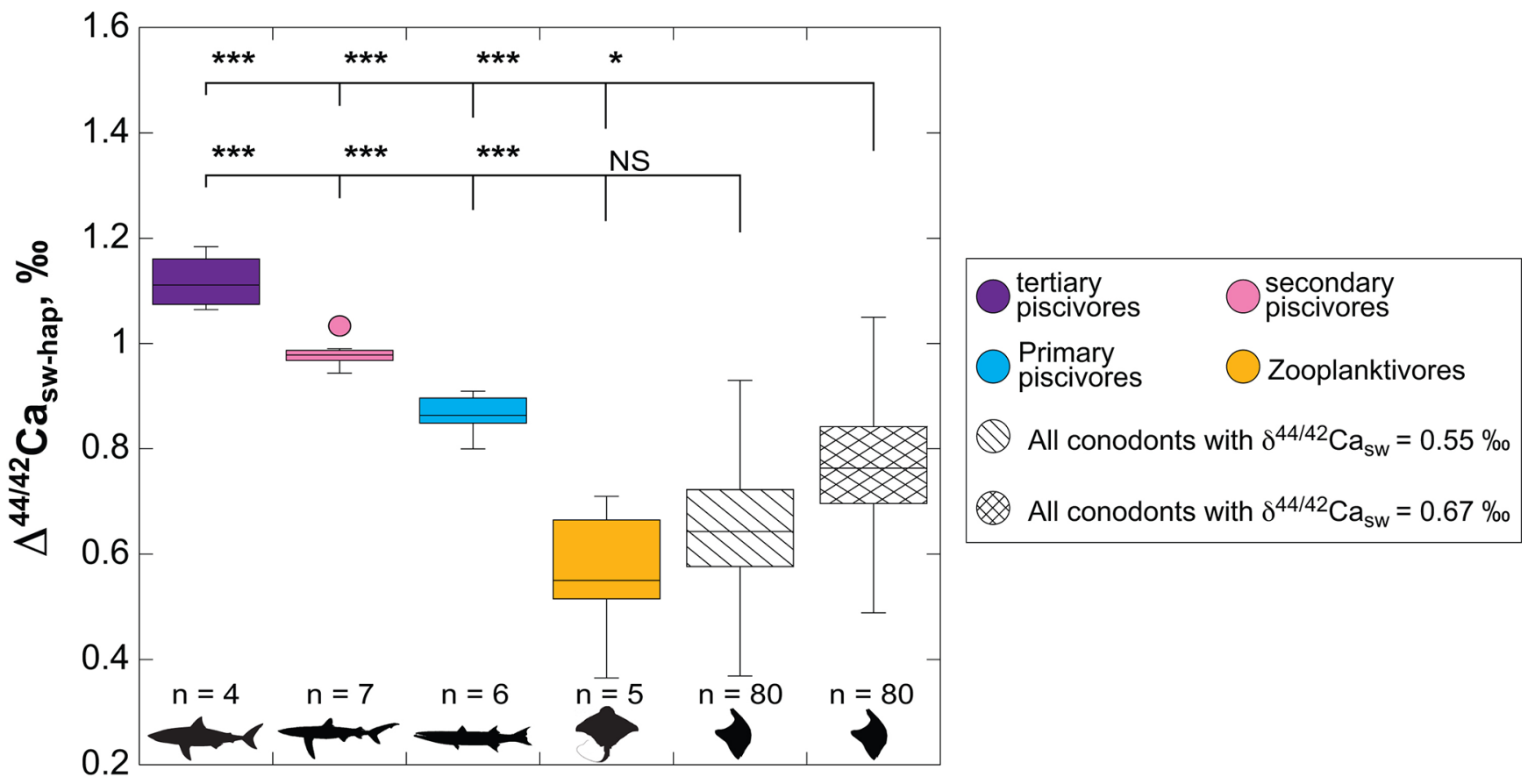

Figure 2 Ca isotopic offset between seawater and hap of modern elasmobranchs compared to that of conodonts $\left(\Delta^{44 / 42} \mathrm{Ca}_{\mathrm{sw}}\right.$-hap $)$ measured in the study. Modern elasmobranch data are from Martin et al. (2015). The $\triangle^{44 / 42} \mathrm{Ca}_{\text {sw-hap }}$ offset is calculated with two $\delta^{44 / 42} \mathrm{Ca}_{\text {sw }}$ values, $0.55 \%$ (diagonal lines) and $0.67 \%$ (diagonal cross hatch) corresponding to the range given by Farkaš et al. (2007; Fig. S-3). Boxplots delimit 5, 25,50,75 and $95 \%$ percentiles. Depending on the $\delta^{44 / 42} \mathrm{Ca}_{\mathrm{sw}}$ value, statistics show that conodonts and zooplanktivores have similar $\delta^{44 / 42} \mathrm{Ca}$ values. Under the null hypothesis that there is no difference in the distribution of two groups of $\delta^{44 / 42} \mathrm{Ca}$ values, the $\mathrm{p}$ value of Student's $t$-tests provides the smallest level of significance at which null hypothesis would be rejected (NS, non-significant $p$ value; ${ }^{*} p=0.01-0.05 ;{ }^{*} p=0.001-0.01$; and $* * * p<0.001$ ).

is subsequently contracted at higher trophic level probably thanks to a biopurification process such as in the case of the $\mathrm{Sr} / \mathrm{Ca}$ and $\mathrm{Ba} / \mathrm{Ca}$ ratios (Peek and Clementz, 2012).

The present results suggest that no significant difference in trophic level may have existed among conodonts, because genera exhibit indistinguishable $\delta^{44 / 42} \mathrm{Ca}$ values (Table S-2). This overall similarity suggests that competition must have existed between some genera occupying similar trophic levels at the same time, i.e. between Palmatolepis and Polygnathus for instance. It is noteworthy that Ancyrodella is the only genus analysed in the study that disappeared at the F/F boundary, questioning the possibility that a distinct ecological trait would have triggered the extinction of this conodont genus.

Using a similar $\Delta^{44 / 42} \mathrm{Ca}_{\text {sw-hap }}$ for conodont elements and modern elasmobranchs to retrieve the trophic position of conodont animals implies similar vital effects (i.e. isotope fractionation due to biological processes) in both groups. This approach is however probably simplistic. In fish, Ca is taken up along three pathways, (1) directly from the water via the gills, which contain a lot of ion-transporting cells or chloride cells (also known as ionocytes), but also through the intestine from (2) drinking water and (3) food (Flik and Verbost, 1993). No evidence for gills has ever been reported in preserved specimens of conodont animals (Aldridge and Purnell, 1996), which would suggest distinct $\Delta^{44 / 42} \mathrm{Ca}_{\mathrm{sw} \text {-hap values between }}$ conodont animals and elasmobranchs. Total intestinal absorption of calcium in marine fish represents around $30 \%$ of the total calcium intake (Björnsson and Nilsson, 1985; Sundell and Björnsson, 1988). To our knowledge, relative proportions of drinking water and food in fish have never been determined, but the isotopic results of Martin et al. (2015) in elasmobranchs demonstrate that food must make a sizable proportion, otherwise no trophic effect would have been observed. Indeed, the most likely explanation to account for the depletion of $\mathrm{Ca}$ heavy isotopes up trophic chains, being marine or terrestrial, is that preys are wholly ingested along with their skeleton which is depleted in heavy Ca isotopes. If the three types of Ca uptake described above are characterised by different isotope fractionation intensity, and their relative proportions vary between fish groups, this should in principle result in a different $\Delta^{44 / 42} \mathrm{Ca}_{\text {sw-hap }}$ fractionation. Analysis of dietary relevant trace elements for marine organisms, such as $\mathrm{Sr} / \mathrm{Ca}$ and Ba/Ca ratios (Balter and Lécuyer, 2004, 2010; Le Houedec et al., 2013; Peek and Clementz, 2012) would corroborate the present results, but we question whether this would be feasible in light of the difference of vital effects discussed above, and of potential diagenetic effects. Further analysis of Ca isotopes in conodont assemblages will document the diversity of their ecological niches within Palaeozoic oceanic trophic chains.

\section{Acknowledgements}

We thank two anonymous reviewers for their insightful comments on an earlier version of the manuscript and $R$. Feist (Montpellier) who provided us with the brachiopod shell analysed in this work. This study was supported by the ANR project Ecodev (ANR-13-BSV7-0005). ISEM contribution 2019-071.

Editor: Ariel Anbar

\section{Additional Information}

Supplementary Information accompanies this letter at http:// www.geochemicalperspectivesletters.org/article1912.

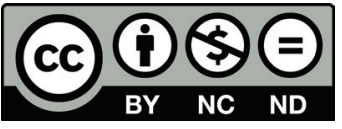

This work is distributed under the Creative Commons Attribution Non-Commercial No-Derivatives 4.0 License, which permits unrestricted distribution provided the original author and source 
are credited. The material may not be adapted (remixed, transformed or built upon) or used for commercial purposes without written permission from the author. Additional information is available at http://www.geochemicalperspectivesletters.org/ copyright-and-permissions.

Cite this letter as: Balter, V., Martin, J.E., Tacail, T., Suan, G., Renaud, S., Girard, C. (2019) Calcium stable isotopes place Devonian conodonts as first level consumers. Geochem. Persp. Let. 10, 36-39.

\section{References}

Aldridge, R.J., Purnell, M.A. (1996) The conodont controversies. Trends in Ecology and Evolution 11, 463-468.

BALTER V., LÉCUYER C. (2004) Determination of Sr and Ba partitioning coefficients between apatite and water from $5^{\circ} \mathrm{C}$ to $60^{\circ} \mathrm{C}$ : a new thermometer for aquatic environments. Geochimica et Cosmochimica Acta 68, 423-432

BALTER V., LÉCUYER C. (2010) Determination of Sr and Ba partition coefficients between apatite from fish (Sparus aurata) and seawater: the influence of temperature. Geochimica et Cosmochimica Acta 74, 3449-3458.

Balter V., Renaud S., Girard C., Joachimski M. (2008) The record of climate-driven morphological changes in 376 Ma old Devonian fossils. Geology 36, 907-910.

Blättler, C.L., Henderson, G.M., Jenkyns, H.C. (2012) Explaining the Phanerozoic Ca isotope history of seawater. Geology 40, 843-846.

BJÖRNSSON, B.T., NILSSON, S. (1985) Renal and extrarenal excretion of calcium in the marine teleost, Gadus morhua. American Journal of Physiology 248, 18-22.

Briggs, D.E.G., Clarkson, E.N.K., Aldridge, R.J. (1983) The conodont animal. Lethaia 16, 1-14.

Clementz, M. T., Holden, P., KocH, P.L. (2003) Are Calcium isotopes a reliable monitor of trophic level in marine settings? International Journal of Osteoarchaeology 13, 29-36.

DePaolo, D.J., (2004) Calcium Isotopic Variations Produced by Biological, Kinetic, Radiogenic and Nucleosynthetic Processes. Reviews in Mineralogy and Geochemistry 55, 255-288.

FARKaš, J., BÖHM, F., Wallmann, K., Blenkinsor, J., Eisenhauer, A., van Geldern, R., Munnecke, A., Voigt, S., Veizer, J. (2007) Calcium isotope record of Phanerozoic oceans: implications for chemical evolution of seawater and its causative mechanisms: Geochimica et Cosmochimica Acta 71, 5117-5134.

FliK, G., Verbost, P.M. (1993) Calcium transport in fish gills and intestine Journal of Experimental Biology 184, 17-29.

GabBott, S.E., Aldridge, R.J., Theron, J.N. (1995) A giant conodont with preserved muscle tissue from the Upper Ordovician of south Africa. Nature 374, 800-803.

GIRARD, C., REnAUD, S. (2008) Disentangling allometry and response to Kellwasser anoxic events in the Late Devonian conodont genus Ancyrodella. Lethaia $41,383-394$

Goudemand, N., Orchard, M.J., Urdy, S., Bucher, H., TAFforeau, P. (2011) Synchrotron-aided reconstruction of the conodont feeding apparatus and implications for the mouth of the first vertebrates. Proceedings of the National Academy of Sciences USA 108, 8720-8724.

Gussone, N., Böhm, F., Eisenhauer, A., Dietzel, M., Heuser, A., TeICHert, B.M.A., ReITNer, J., WÖRHeIDE, G., Dullo, W.C. (2005) Calcium isotope fractionation in calcite and aragonite. Geochimica et Cosmochimica Acta 69, 4485-4494.

Hinojosa, J.L., Brown, S.T., Chen, J., DePaolo, D.J., Paytan, A., Shen, S.-Z., PAYNE, J.L. (2012) Evidence for end-Permian ocean acidification from calcium isotopes in biogenic apatite. Geology 40, 743-746.

Jost, A., Mundil, R., He, B., Brown, S.T., Altiner, D., Sun, Y., DePaolo, D.J., PAYNE, J.L (2014) Constraining the cause of the end-Guadalupian extinction with coupled records of carbon and calcium isotopes. Earth and Planetary Science Letters 396, 201-212.

Le Houedec, S., Girard, C., Balter, V. (2013) Conodont Sr/Ca and $\delta^{18} \mathrm{O}$ record seawater changes at the Frasnian-Famennian boundary. Palaeogeography, Palaeoclimatology, Palaeoecology 376, 114-121.

Le Houedec, S., McCulloch, M., Trotter, J., Rankenburg, K. (2017) Conodont apatite $\delta^{88 / 86} \mathrm{Sr}$ and $\delta^{44 / 40} \mathrm{Ca}$ compositions and implication for the evolution of Palaeozoic to early Mesozoic seawater. Chemical Geology 453, 55-65.
Martin, J.E., TACail, T., Adnet, S., Girard, C., BAlter, V. (2015) Calcium isotopes reveal the trophic position of extant and fossil elasmobranchs. Chemical Geology 415, 118-125.

Peek, S., Clementz, M.T. (2012) Sr/Ca and Ba/Ca variations in environmental and biological sources: A survey of marine and terrestrial systems. Geochimica et Cosmochimica Acta 95, 36-52.

Purnell, M.A. (1995a) Large eyes and vision in conodonts. Lethaia 28, 187-188.

PURNELL, M.A. (1995b) Microwear on conodont elements and macrophagy in the first vertebrates. Nature $374,798-800$

Purnell, M.A., Donoghue, P.C.J. (1997) Architecture and functional morphology of the skeletal apparatus of ozarkodinid conodonts. Philosophical Transactions of the Royal Society 352, 1545-1564.

Shirley, B., Grohganz, M., Bestmann, M., Jarochowska, E. (2018) Wear, tear and systematic repair: testing models of growth dynamics in conodonts with high-resolution imaging. Proceedings of the Royal Society B: Biological Sciences 285, doi: 10.1098/rspb.2018.1614.

SkUlan, J., DePaolo, D.J. (1999) Calcium isotope fractionation between soft and mineralised tissues as a monitor of calcium use in vertebrates. Proceedings of the National Academy of Sciences USA 96, 13709-13713.

SkUlan, J., DePaOlo, D.J., OWENS, T.L. (1997) Biological control of calcium isotopic abundances in the global calcium cycle. Geochimica et Cosmochimica Acta 61, 2505-2510.

SundelL, K., BjöRnsSON, B.T. (1988) Kinetics of calcium fluxes across the intestinal mucosa of the marine teleost, Gadus morhua, measured using an in vitro perfusion method. Journal of Experimental Biology 140, 170-186.

Tacail T., Albalat E., Télouk P., Balter V. (2014) A simplified protocol for the measurement of $\mathrm{Ca}$ isotopes in biological samples. Journal of Analytical Atomic Spectrometry 29, 529-535. 